\title{
OBITUARY
}

\section{HILDEBRAND WOLFE HARVEY}

The death on 26 November 1970 of Dr H. W. Harvey, F.R.S., within a month of his eighty-third birthday, marked the passing of one who brought great distinction to the Marine Biological Laboratory.

At Cambridge in 1910 he had passed the Natural Science Tripos (Part II) in Chemistry and undertook research under Dr W. B. (later Sir William) Hardy, F.R.S., whose influence remained always with him. A keen yachtsman with a certificate as Master Mariner (Yacht), it was natural for him to serve in the R.N.V.R. through the First World War as a navigating officer of small craft, mostly in northern Russian waters. This experience served him well during his years at Plymouth. He joined the staff of the Laboratory on 1 October 1921 and retired on 31 March 1958.

The survey of the oceanographic features of the English Channel had been started on modern lines by D. J. Matthews in 1903, and Harvey's first task was to restart this after the war on a monthly basis in terms of measurements of temperature and salinity. This led to a number of publications which others found valuable but which did not satisfy himself. From the beginning a study of biological productivity was in his mind and there was a short questing period while he sought how best to set about it. W.R.G. Atkins, F.R.S., had joined the staff at much the same time, and with Dr E. J. Allen, F.R.S., as Director it was not surprising that both had turned their thoughts to a quantitative study of plant nutrients.

Harvey sought a method for determining nitrate in sea water since the methods of the day were quite inadequate. He found it in a method based on a reduction product of strychnine in solution in sulphuric acid. He never claimed that it could give more than 'good rough quantitative data' but for more than a decade it was used in nutrient researches in all the world oceans. It has been replaced, but with Atkins' methods for phosphate and silicate it was sufficient to give the broad picture of nutrient distribution which we now have.

However, his most important contribution in his first decade at Plymouth was his book Biological Chemistry and Physics of Sea Water, published in 1928. In a slender volume of 194 pages he synthesized the knowledge of the time on water movements, temperature, illumination and chemistry of sea water as factors which control the density of plant production and population. The preparation of this book before he started his main life work was typical of the ordered and economic way he conducted all his research, first to read, think and co-ordinate existing knowledge, then deliberately to sit back and design experiments capable of giving him unequivocal advances, and finally to carry these through with great care for essential detail and with no time wasted on anything irrelevant. He was a master of the experimental method.

It was at this time that he became interested in river and estuarine pollution, but it is typical of his method that he condensed a considerable amount of his own experimental 
work into one single short article in Nature. His later contribution to pollution research cannot be assessed from published literature; it was the general supervision of the survey in 1929-33 of the estuarine part of the Tees, a research undertaken by the Marine Biological Association on behalf of the newly formed Water Pollution Research Board. Dr B. A. Southgate was the first chemist employed by the Board and later became its Director. He writes that the objective was to find an answer, in a limited time and with meagre resources of staff and equipment, to the pollution of the River Tees at a time when nothing of consequence was known of the current system and ecology of an estuary nor of the nature of the toxic constituents of the industrial effluents being discharged to the Tees nor of their effects on fish. Harvey accepted these conditions and maintained his enthusiasm throughout the survey. Southgate and his colleague benefited greatly from Harvey's association with the work and from his encouragement.

Valuable though his early hydrographical work had proved, nevertheless his genius seemed slow to flower. He had been on the staff for twelve years before producing his classic paper On the Rate of Diatom Growth, but after that the flow was fast. He designed and made the tools that the job needed. There was also need for a collaborative study of the interplay of physics, chemistry, plant physiology and zooplanktology. Harvey designed this and not only did most of the sea work but also most of the continuing thinking. The writer played the part of no more than a chemical technician, but the resulting publication on 'Plankton Production and Its Control' is one of those with which he is most proud to have had his name associated.

The lines of Harvey's work bifurcated, one line dealing with the grazing of phytoplankton and the other with the uptake of required chemicals by plant cells, notably of iron and manganese.

After the Second World War he returned to chemical methodology, devising for sea water better analytical methods for the elements which he had found essential for the successful growth of plants. At that time no analytical spectrophotometer could be bought commercially so he designed one applying inverse square law principles to the selenium photocell. For some years this instrument enabled the laboratory to work with much increased precison before commercial instruments became generally available.

He wrote two further books, Recent Advances in the Chemistry and Biology of Sea Water published in 1945 and The Chemistry and Fertility of Sea Waters published in 1957, each containing much well-organized information in a small space. His books were translated into several languages and have exercised profound influence on the development of marine chemistry and of the study of marine productivity.

Harvey was elected in 1945 to Fellowship of the Royal Society and in 1953 he was awarded the Agassiz Medal of the U.S. National Academy of Sciences. As an independent assessment of his achievement it is interesting to quote from the Report of the Murray Committee which recommended the award: ' $\mathrm{H}$. W. Harvey... has been the leading student for many years of the changes in the chemical constituents of sea water brought about through the agencies of plants and animals and also of how the availability of nutrient chemicals determines the fertility of the sea. While his field observations have been concentrated mainly in the English Channel and its approaches, many of the con- 
clusions which can be drawn from his work apply to the whole biologically active zone of the marine environment'.

Harvey's genius lay in recognizing untilled fields ready for strategic research and in his gift for cultivating those fields with maximum production of pertinent knowledge. No effort was wasted in nurturing trivial weeds. The Marine Biological Association was fortunate in finding Harvey but also he was fortunate in finding the Marine Biological Association as the place to pursue his bent with great freedom to plough his own furrows as he thought best. At the time, an inspecting committee of wise men might well have thought that some of those furrows were not being ploughed straight. Only time has shown that each was the shortest which could attain the end.

His career has a lesson for us today with the pressures to plan our work towards quickly 'useful', economically profitable ends. This indeed was what he did but his progress in his first decade on the staff must have appeared leisurely. His methodical preparation of the ground for the rich flowering in the 'thirties could not have been obvious in the 'twenties.

He was not the narrow specialist which his reserved manner suggested to some but one prepared to search any discipline for the information he needed. Outside of his scientific interests he was a good wood-carver, cabinet-maker, mechanic and artist. He designed M.V. 'Gammarus', which served the Laboratory so well for work in and around Plymouth Sound for nearly half a century. It was fitting that when she had finally to be replaced Mrs Harvey honoured us by launching and naming her successor 'Gammarus'.

A fuller notice and a list of publications will appear in the Biographical Memoirs of the Royal Society.

L.H.N. COOPER 
J. MAR. BIOL. Ass. U.K., 52 (3)
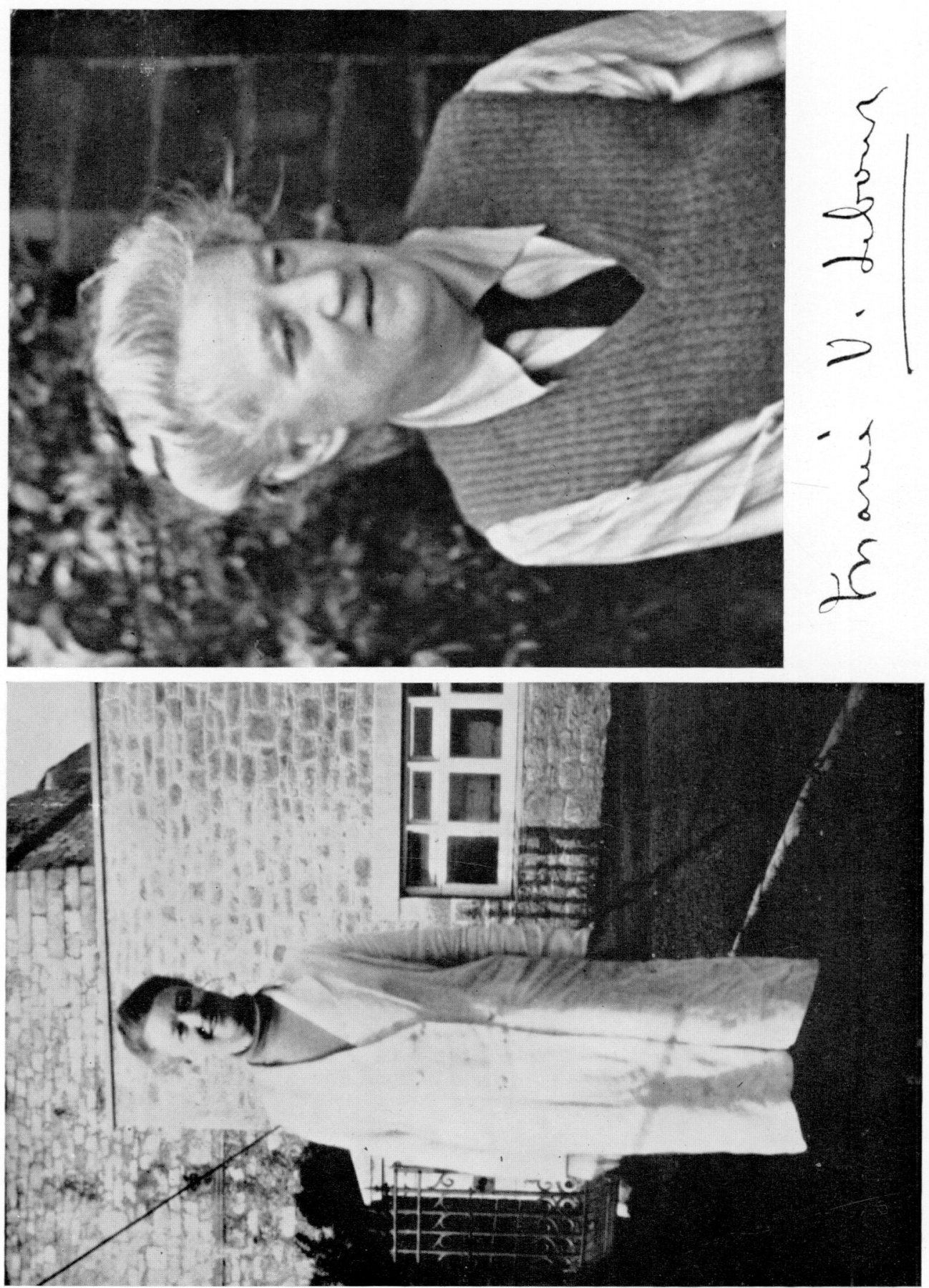

告 